\title{
Overview-Ecological Management Connecting Green Knowledge Management and Organizational Performance
}

\author{
M. Suba, S. B. Inayath Ahamed
}

\begin{abstract}
The ecological human capital management is almost

focusing on the human administrative practices of the organization. But the ecological personal administrative practices are not only created for the human resource practices it's also encompass a second elements that is preservation of knowledge capital. Lot of researcher has studied on the green human force management with the base of human force management practices. This article like to examine the concept of knowledge sharing management and how its impact on firm's performance.
\end{abstract}

Key words: Ecological manual force, comprehensive management, environment management.

\section{INTRODUCTION}

In present days the Environmental human resource management is one of the important focuses in the all industries. In current status every organization should involve in the green functioning for their survival. The fulfillment of new job or rules the employee should adopt with the organizational policies and teams like wise they should galvanized, enabled, and ecologically knowable of environmental routines in sort to execute nature friendly work. The basic requirement of action planning of green management is employee involvement for the assimilation of eco-friendly management into Human Force Management. The management human force execution could be impact is making possible in embracing advances for making a civilizations of feasibilities. The tactic approaches occupies executing transforms to the dissimilar purposes of human resource such as staffing, initiation, guiding and improvement, effecting performance valuations, as well as deciding workers salary and rewards. The textile dissection is the next main way of service behind forming and therefore cannot be unobserved: intimidating the government to encompass the industry among the 25 significant partitions, which has the possible to content with the mainly exceptional in the world, for moving green assignment. For the reason that this production industry have ever been contributing largely to Gross Domestic Manufactures, employment initiation, whole industry manufacturing process, etc virtually a thousands and a thousand employees are get move on occupied in the textile industry making processes.

Revised Manuscript Received on December 15, 2019

M. Suba, Kalasalingam Academy of Research and Education (Deemed to be University), India

Dr. S. B. Inayath Ahamed, Assistant Professor, Kalasalingam Academy of Research and Education (Deemed to be University), India.
It eddies to be indispensable to work outs its results in the most recent preceding to determine how it can be supplement are browbeaten in standpoint of moving green associations whichever can motivates creating and work configuration in the separation. Results in any business workout the phase of produce along with employment. As the consequence of the researcher are predicted to notice the production and manufacturing competency by the attentiveness of Ecological Human Resource Management (Dr. Asiya Chaudhary Mohammed Pervej and Neshat Anjum, 2016).

In the olden days of the country is only concentrated on their improvement. These conditions create lots of business entities. After this creation the competitive world stimulates these organizations to take some actives like unwanted use of resources and excess use of resources. By these day to day actives we made a major damage to the society. Lot of issues are happened by this kind of actions like global warming and the changes in the climate resulting into earthquakes, ecological imbalance, frequent floods and vanishing of certain species and animals. This environmental result highly reflected among the society. As a result for the society realized the sustainability is also depends on healthy environment. Implementation of this concept can make better brand image and give proper response from the society to the industry people. The ecological response of the individual is termed as CSR and in the administrative view it is termed as Green HRM.

\section{ECO-FRIENDLY HUMAN FORCE MANAGEMENT (E-HFM)}

Current scenario the significance of ecological problems and durable improvement has amplified mutually in the improved and improving nations. Developing interest for international ecological and enrichment of intercontinental values for ecological administration has formed a requirement for the firm to implement "ecological strategies". With these stress business associations today have become added aware about the increasing significance of the assimilation of ecological administration and personnel administrations for example: ecological human capital management strategies.endorse the supportable use of resources along with the business association and more commonly, develops the reasons of ecological viability. It engages $\mathrm{hr}$ proposals to support viable strategies and raise workers consciousness and involvement on the questions of viability.

Ecological Human Resource stows of two indispensable constituents: Eco-affable Human Resource policies with the conservation of comprehensive prime.

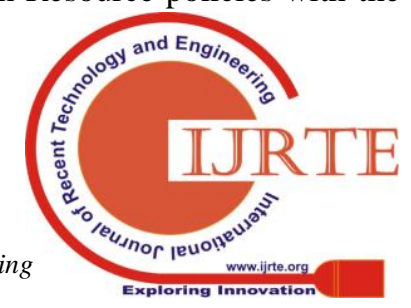


It necessitate accountable eco-friendly proposals consequential into better competency, low cost, and good worker commitment and preservation which in turn assist business associations to lessen carbon emissions. In verity Ecological Human Resource strategies concentrates on cooperative and personal abilities to fetch about eco-friendly attitudes. These practices are indented at improving an ecological communal ethnicity. Ecological Human Resource concentrates on workers performance in the organization, as a result, would be conceded on to utilization method into their personal existence (Schrader and Muster 2011).

Study in this area of Ecological Administrative schemes discussed that Ecological Administrative Method (EAM) can merely be efficiently executed if the organization has the worker with required knowledge, ability and proficiency (Daily and Huang 2001).A the result of these schemes demands a top most degree of practical and administrative abilities among workers (Callenbach et. Al., 1993) so Ecological Human Resource inventiveness entangles the accomplishment of staffing policies, recompense and recitalbased monitoring methods, and also the training programs focused at raising the workers ecological consciousness.

In the ecological reviews, the idea of Ecological administration for the viable improvement has a range of descriptions; all of which commonly, pursue to elucidate the requirement for manage between manufacturing growths for affluence making and protecting surrounding for that the forthcoming lifetime might flourish (Huang and Daily, 2001). Although business at present have been running on product advancement for ecological viability besides the concern of how the single business or whole society attains viability from the Ecological Administration progress is still controversial and uncertain. As a result of this study efforts to specify a development structure of the Human Resource strategies concerned in Ecological Human Resource Management on the justifications of the available reviews. This article too inspects the nature and level of Ecological Human Resource ideas undertaken in the Textile industries.

The human resource management recently connected with the environment management because it can simplify the process for HRM and EM. The actual human resource management is almost covers and executes all the process of the organization for that the management can do two kinds of with single name and employees. This will minimize the work and give better outcome. The embodiment of ecological intention and policies into the complete deliberate improvement aspiration of a concerns assist into attaining by the side of Resource Management (HRM) because it is fundamentally or highly significant rather than just enviable. At the present days it gives an impression that a sustainable number of administrative practice ecology Human Resource Management in the intercontinental conditions (Opatha et al., 2015).

At present, the range of literate populace is raised, consequently it reflects on the awareness of green. By this the organizations that are all follows the green behavior can easily get spirited advantages in a short time. There is necessitate for corporation to accept prescribed ecological strategies outstanding to mounting global ecological involve and improvement of worldwide ecological principles (Daily and Huang, 2001). Numerous reviews on ecological logistics

(Peattie, 1992), Eco-affable assessment ecological accounting (Bebbington, 2001; Owen, 1992), ecological Retailing (Kee-hung et al., 2010), and ecological admin in common (Protheroet et al, 1997) encompass inseminated the idea of ecological administration keen on manual force (HR) baptize eco-affable manual force (Dutta, 2012).

Literature enclosed significance near espousal of ecological strategies towards recognize the manual force execution routines (Cherian et al., 2012). (Haden et al., 2009) perceive that the incorporation of ecological intentions with approaches besides in the midst of deliberate improvement purpose of corporation outcomes in an efficient ecological administrative method. (Huang et,al.,2001) contrived so as to associates basically necessitates in the direction of compensate the manufacturing expansion over and above conservation of the surrounding for the reason that it has been substantiate with the aim of approve eco-affable strategies, the organization could returns added that prior to (Murari et al., 2011). The manual force role of a business entity performs a consequential part in the conception of their company's integrity grace (Wirtenberg et al., 2010). It is recognized that the superior the force on ecological manual force strategies, the exceeding is the concentration of espousal of Ecological Administrative System (EAS) with strategies by the various companies (Novotna, et, al., 2011).

\section{THEORETICAL BACKGROUND OF GREEN HRM}

The topic of Ecological Human Resource Management has come out with the beginning of Ecological Management. Ecological Administration is a supporting operation which counsels four significance standards: Green politics, viability, Non- aggression and social fairness. Follower of the Green operations are called "greening" stick on to Ecological philosophy and split more thoughts with environment, preservation, ecology, libber and calm actions. With the raising consciousness of the ecological process cross wise the globe, management scholars from varied field such as finance, advertising, supply chain administration and Human Resource Management too begin examining that how administrative strategies in these Heretofore now-a-days, the United Nations word in alliance with various edifying associations has improved the (PRME)"Principles for Responsible Management Education", motivating researchers and executors to mutually works to generate new ideas to improve ecological responsibility (PRME, 2010). In verity the improvement with the implementation of a commercial ecological proposal, engross many segments of the association seeing that a team course of action as a result of liabilities so diverse role be take on. Part of the major significant providers for these proposals is the Manual Force Management of the organization. The Human Resource Management does not only speak for a major share holders inside the organization, but it is also a source for viable benefits (Snell, et, al., 2007).

Presently, most companies are executing a proactive, practical tool known as an Ecological Management System to get spirited benefits (Daily and Huang, 2001).

This method gives a model that 
permits management of the business entity the capability to good manage the organization's ecological influences (Barnes, 1996; Florida and Davison, 2001). Nevertheless it is retained by most that the part of workers commitment in the Ecological Administrative Method has one of the major bases those impacts on its efficiency and accomplishment.

Sudin (2011) argued the good result of the kind of Environmental cerebral capital on corporate ecological citizenship, guide to the spirited benefits of the organizations. Therefore there is a requirement refining human resource part from human resource administrators those attains workers cooperation in executing ecological strategies (Wehrmeyer and Parker, 1996).

Alongside this backdrop it can be unspecified that Ecological Human Resource Management is all concerning the comprehensive solicitation of the idea of viability to firm and its labor force. It commits Ecological behaviors concentrates on raising effectiveness within the procedures, lessening and removing ecological waste, and overhauling human resource products, kids, and events ensuring in good effects and minimize the cost. The consequences encompass: technical filing, travel sharing, teleconferencing, and virtual interviews, re-producing, and improving more power capability office places.

In verity Ecological Human Resource Management improves a variety of eco-friendly procedures and strategies in distinct human resource operations. Several strategies pertaining to eco-friendly administration in which human resource is spiritedly encaged have been defined above. Purposively the operational fields where human resource can have ecological approaches have been discussed in the following sections.

\section{PROBLEM AND OBJECTIVE OF THE STUDY}

The main aims of ecological human resource management are lessen the harmful effects on environment, reduce the wastages. Form the result of this objective we have some spirited benefits there are for lessening the harmful effect we can give work from home, online interviews etc. And to reduce the wastage we can go for the second production with the wastage of the first product it will simplify the work and also give extra benefits to the organization. The requirements of making ecology are to utilize the products and the way that

should not badly influence the ecological system due to contamination and diminishing the global resources (Robinson, 2008). If the utilization of environmental resources is lessen by utilizing the substitute resources, it may have better results such as remain the ecological footprint small, lessening trash and re-produce materials as much as possible (Dallas, 2008). In advance, it may consequence in utilizing in short supply of environmental resources proficiently and successfully, even as enduring the surrounding released from the harmful products.

Researcher in this field discussed that the structure of ecological administrative method can only be successfully executed if the organizations possess the better employee with the good skills and knowledge (Daily and Huang, 2001). Strategically Human Resource Management discussed that to attain Human resource efficacy, Human Resource should be trained as a whole and should be arranged with the organizational premeditated goals, the primary means by which the organization can impacts and outline the knowledge, attitudes, and deeds of persons to do their work and thus attains the firms goals (Collins and Clark, 2003). Before hand, organizations unspecified that incorporating 'ecology' within the organizational practices should cost money, nevertheless at present they experience that take no notice of harmful impacts on the surrounding will be pricey in the forthcoming (Van der Zee, 2008).

From the previews reviews of the green human resource management the researcher like to study what is knowledge management, how its comes under the green human resource management, what are all the effects and innovative the organization should take for the implementation of knowledge management in their organization, finally the researcher wants to examine how the knowledge management reflects on the organizational performance.

\section{PROPOSED MODEL}

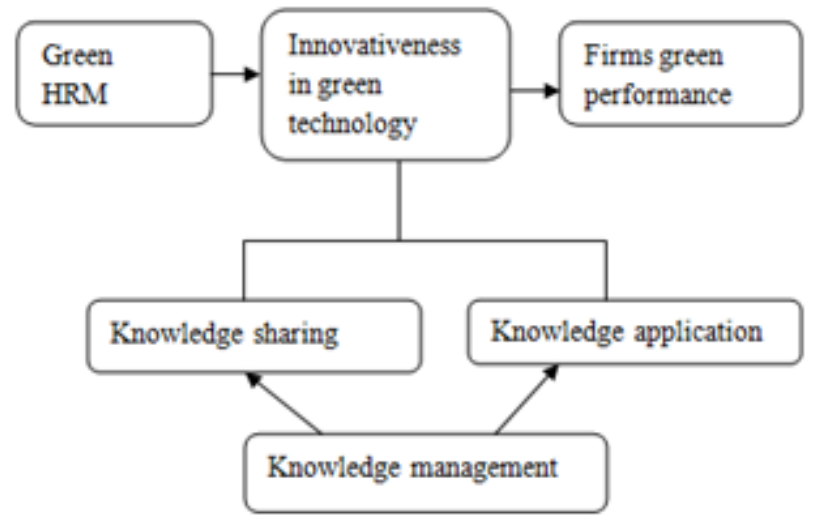

VI. KNOWLEDGE MANAGEMENT

In every organization the human force is the essential resource. The workers of the firm can give their full effort to execute the firm's objectives for the better utilization of work force the organization should

support knowledge administration. To research the viability objectives, knowledge administration (KA) may be considered as middle central

(Gloet, 2006; Robinson et al., 2006). There is most diverse

\section{Performance}

standpoint as how to describe KA. A functional explanation is to see KA as a technical path of making, splitting, and leveraging knowledge inside and around the business associations (Bounfour, 2003). This elucidate that KA has a long-range course and consequently suits politely with one of the fundamental suppositions of viability and viability administration that is viability (Chow and Chen, 2012). KA strategies, for instance knowledge conception, knowledge broadcasting, knowledge storage and knowledge application, 
are anticipated to assist a improvement of knowledge that is advanced and apropos. Therefore, viable Knowledge Administration can be observed as an abridgment of Knowledge administration and integrality; where the main part of Knowledge Administration is to care for present and prospective knowledge reserves viable by think about communal, financial and ecological features (Ansari et al., 2010). This concise conversation also guides us to the approaches to attain the objectives. It could also highlights the typical requirements of encompassing included these Knowledge Administrative practices in the complete organizations policies (Hansenet al., 1999).

\section{A. Knowledge administrative policies and practices}

There is a common unanimity in existence reviews that Knowledge Administration is the base on which organizations metamorphose knowledge into fruitful operations. Knowledge Administrative assists in improving knowledge to the correct individuals at the ideal time augment manufacture and lessen the supply chain amount and thus can enhance the spirited benefits of the organizations. As a result of, Knowledge Administrative shapes the essential posterior for the improving and implementing Knowledge administrative practices. Consequently, by encompassing a correct Knowledge Administrative practices in place, organizations can direct their Knowledge more successfully. Knowledge Administrative practices are utilized to assist organizations in ascertaining "what to do" within the knowledge to attain particular goals. Knowledge Administrative practices speaks should be lineup with the organizations business practices. Zack says that advancing the inside knowledge is the major conservational knowledge practices the organizations can implement. These business associations (internal workers) encompass adequate knowledge reserves to keep their selves spirited in their fields. On the other side, associations that concentrate both on prospecting outside knowledge reserves to improve fresh knowledge base and developing internal knowledge bases to look for organizational possibilities can be contemplate of as utilizing the major forceful knowledge policies. the "how to do it" question as well (Asoh et al., 2003). At what time dealing with knowledge Administrative practices, it is significant to discriminate between various kinds of policies. Zack (1999), for instance, suggested a outline of Knowledge Administration practices that they support These organizations ("unbounded trailblazers") center on both gaining learning capitals from their outside condition and making benefits by using it. Zack contends that organizations working in learning escalated ventures would

have better execution contrasted with their rivals on the off chance that they utilize generally forceful information methodologies.

Hansen et al. (1999) acknowledge two types of KA policies: systemization and individuation policies. A systemization policy is Information technology related, it highlights the systemization of knowledge and its storeroom in the database, so persons working in the organization can clearly repossess it. Personification practices is workers-related, it is concentrates on Knowledge sharing among workers, and significances of constructing appropriate Knowledge

information technology methods are used for assisting people conserve knowledge, thus their functions goes beyond clean knowledge storage.

The usage of a personification practices is a type of strategic thoughts that begins from and close to people. The organizational behavior of the business approving this strategy mostly relies on their workers implicit knowledge rather than on their subsisting define knowledge. Accordance with Choi and Lee (2002) studied the impacts of knowledge policy to knowledge generation proceedings in a sample of 58 Korean associations. The researcher found people and system based Knowledge practices. The system based knowledge highlights systemization, reserving, data system, etc, and assays to share knowledge properly with information technology network, software, documents etc. The human practices concentrate on conversation among the workers in social networkers, and assays to staffing knowledgeable and skilled workers and stresses easily shared knowledge in knowledge collectives, conversation groups/ dispute meeting etc.

Primary research encompasses also accentuated the process to improve system and human related practices. This researcher can be categorized into trio base: stable, active and centered. These investigation suggested organizations to elect a kind of practices that is major or one which finest serve up the knowledge generation, sharing and exploitation needs and utilize the other one as a form of assistance. The stable view recommended that organizations require attracting a balance among the two approaches. . Kumar and Ganesh (2011) identified those organizations that unite "human" -related policies with a "system"-related policies to get and sharing knowledge are more gainful. Liu et al. (2013) affirmed that organizations a forceful policies which incorporate a human resource direction and a system direction attaining good recital than the organization with a less assertive policies.

The spirited viewpoints recommend that organization alter their approaches to the individualities of the knowledge concurrent. For instance, directors should alter knowledge Administration with the responsible traits. The concentrated perceptions recommend organizations to look on a particular policy. By different, the stabled and active apparitions demand that organizations should implement both kinds of practices. The spirited perceptions, conversely, doesn't acquire into account the vital nature of knowledge. The active perception recommends that the options of the policy kinds will diverge depending on the distinctive of knowledge Choi and Lee (2002). At the point when a firm endeavors to actualize the two systems, with rise to accentuation given to both, the outcomes can bring about gambling a total technique disappointment. Both practices can in fact be applied, other than this conversation is seemingly suitable only for cosmopolitan associations that encompass comparatively typical and information and communication technology (ICT) exhaustive operations to connect the two practices, other than it is not suitable for small and mediumsized companies (smes; Shackelford and Sun, 2009 ). 
In whole, one can reason that any KM technique ought to be executed as per the structure and attributes of the organization concerned. A few creators ( Asoh et al. , 2003 ; Sabherwal, et al., 2001) contended that organizations can enhance hierarchical execution by deliberately adjusting their business procedures to their KA techniques. Such creators presumed that utilizing distinctive KA systems at various phases of the business life cycle is additionally basic, as organizations have diverse information needs in various stages. In that capacity, the selection of KA systems can prompt better execution.

\section{SIGNIFICANCE OF ORGANIZATIONAL CIVILIZATION IN FIRM"S INNOVATIVENESS}

Approaching a communal- circumstances theory of HRM, associate ethnicity placed as a predecessor of workers approaches and performance. An intentionally practical Human Resource makes a commercial culture of improvement and inspiration that is essential for implementing organizational practices.There is a requirement to improve the methodology- supported traditions in methodological- exhaustive manufacturing industries, given that only with the advanced civilization that is concerned obtain jeopardy, workers involvement, ingenuity, and joint accountability; a company can be spirited in a fresh product improvement. To advance this method of civilization, workers should be direct approaching stable erudition, cooperation, and a substantial level of work freedom. The method that deliberately schedules to change workers plans against innovation would effect in the modernized culture. It go behind that business civilization is an superseding constitutes among deliberated Human Resource Management system and organizational uniqueness in ecological expertise (C. M. Lau, and H. Y. Ngo 2004).

\section{B. At the view of training}

The knowledge management is a new process so the organization should give a proper training for the better use of human force in the work place. At the point of training every organizations gives a proper guidance to their workers regards their daily process. But if it is comes from knowledge sharing the work will be completed in a targeted time. The hasty walk of industrial growth ever more creates the part of training significance. Seeing as knowledge and ability that obtain during proper guidance or preceding training will devalue and turn out to be supersede, the employees requirement to be frequently occupied in an enduring procedure of abilities attainment (C. M. Lau, and H. Y. Ngo 2004).

Training enriches workers' knowledge and ability that are decisive to fresh product improvement. In examine the firm's functional development, it is originate that high profitable business associations use major time on instruction and

guidance, not only on industrial mission linked ability nevertheless on communiqué and joint effort abilities (C. M. Lau, and H. Y. Ngo 2004). Conversely, to attain firm's usefulness, Human resource training should be harmonious with the organizational policies and work progression. In common, training- centered Human Resource strategies improve the human force to attained spirited improvement in promotes (C. M. Lau, and H. Y. Ngo 2004).

\section{Recital based rewards}

Training gives the chance for personal and associations to improve suitable proficiencies. But, to continue rivalry, erudition attitudes have to be honored specifically when individual performance has developed. Human force method with performance- connected awards has optimistic consequence on the business performance arbitrate by workers ability, knowledge and actions. Recital based awards can stand for an assurance to workers, gives for inventiveness, and afterwards add force to innovative performance. In this research of creative products improvement, performance- based award has been measured to be important.recompense tool. Various advanced- tilting organization have been concentrate on a variety of recompense package to award TQM (Total Quality Management) and workers commitment. In other words, recital- based salary is habitually found in Green human Resource method that supports innovation.

\section{Joint effect}

The simple concept of every business associations are spit and arrangement of output. Because in management view without the group of people nothing is possible. Many technical-base analysis have (S. Ahmad, and R.G. Schroeder 2003, G. W. Bohlander, and S. A. Snell,2003, C. M. Lau, and $\mathrm{H}$. Y. Ngo, 2004), exposed that joint effect plays a serious part in extracting innovation. Joint effort improvement and increase productivity, uniqueness, and workers confidence. A business association requires examining the abilities and action preference of team workers, emphasizing power and recognizing field for the joint development. Efficiently a group development program motivates teams to think as a whole and gives personal improvement a range of inter individual proficiency communiqué, guidance and encouraging abilities.

\section{E. Managing Knowledge Workers}

Right people at the right skills of the basic formula of manual force administration, but in the concept of knowledge assessment right people can make right peoples at right time. Vicissitude proposal depend extremely on workers skills, expertise, and promise as main effort in the worth making procedure R. M. Hodgetts, and K. W. Hegar (2004). Given that organizations facilitates to admittance the awareness and proficiency of the workers, they execute to make certain the consumption of the Human Resource in the accomplishment of administrative goals (S. Sudin 2011). In the present year majority of the most gainful business entities have been those that have effectively directed the skilled employees.

\section{Performance}

Occasion a business firm has recognized its regulations, it be obligate to improve knowledge application and the knowledge sharing culture (C. M. Lau, et al., 2004). 
The knowledge- placed focal point believes organizations as archives of ability and capabilities. Accordance with this review, ability and capability of man force are documented as priceless prime of the organization for the reason of their individualities. While comprehensive- placed resource are communally, complicated and typically hard to emulate, assorted knowledge bases and abilities of the organizations are the key determinants of continued benefits and better communal recital (G. W. Bohlander, and S. A. Snell 2003).

\section{CONCLUSION}

Green human manual force administrations have a basis two elements one is eco-friendly exploit of prime into the routines. Also the other is preservation of knowledge capital. This article is created to examine the above statement. From some of the effective literature review the article has been created. This conceptual work will be moves to the extension of comparative and empirical work in the upcoming articles.

\section{REFERENCES}

[1] Ansari Ch F, Holland A, and Fathi M (2010) Advanced Knowledge Management Concept for Sustainable Environmental Integration. IEEE 9th International Conference on Cybernetic Intelligent Systems (CIS), 1-2September, 1-7.

[2] Asoh, D. A., Belardo, S., and Duchessi, P. (2003) Alignment: The Missing Link in Knowledge Management Research, Proceedings of the 4th European Conference on Knowledge Management, Oriel College, Oxford University, UK, pp. 39-48

[3] Barnes, F.C. (1998) ISO 9000 Myth and reality, a reasonable approach to ISO 9000, SAM Advanced Management Journal, 63, 2, pp.23-30.

[4] Bebbington, J. (2001). Sustainable Development: A Review of the International Development, Business and Accounting Literature. Accounting Forum, 25, 128-157.

[5] Bohdanowicz, P., Zientara, P., \&amp; Novotna, E. (2011). International Hotel Chains and Environmental Protection: An Analysis of Hilton's we Care! Programme (Europe, 2006 2008).Journal of Sustainable Tourism 19, 797-816. Doi: 10.1080/09669582.2010.549566.

[6] Bounfour, A. (2003) The Management of Intangibles: The Organization's Most Valuable Assets. Routledge, London, New York.

[7] C. M. Lau, and H. Y. Ngo, The HR system, organizational culture, and product innovation. International Business Review. J., vol. 13, no.6, pp. 685-703, Dec. 2004.

[8] Cherian, J., \&amp; Jacob, J. (2012). A Study of Green HR Practices and Its Effective Implementation in the Organization: A Review. Internationa Journal of Business and Management, 7, 25-33.

[9] Choi, B., Lee, H. (2002) Knowledge management strategy and its link to knowledge creation process, Expert Systems with Applications, 23(3), 173-187.

[10] Collins, C. J., \& Clark, K. D. (2003). Strategic human resource practices, top management team social networks, and firm performance: The role of human resource in creating organizational competitive advantage. Academy of Management Journal, 46 (6), 740-51.

[11] Daily, B., \&amp; Huang, S. (2001). Achieving Sustainability through Attention to Human Resource Factors in Environmental Managemen International. Journal of Operations \&amp; Production Management, 21(12), 1539-1552. Doi: 10.1108/01443570110410892

[12] Dallas, N. (2008). Green business basics: 24 lessons for meeting the challenges of global

[13] Dutta, S. (2012). Greening People: A Strategic Dimension. ZENITH: International Journal of Business Economics \&amp; Management Research, 2, 143-148.

[14] Fayyazia, M., Shahbazmoradib, S., Afsharc, Z., \&amp; Shahbazmoradic, MR. (2015). Investigating the Barriers of the Green Human Resource Management Implementation in Oil Industry, Management Science Letters, 5, 101-108.

[15] G. W. Bohlander, and S. A. Snell, Managing Human Resources (13thed.), Boston, Massachusetts, United States: South-Western College Pub., 2003.

[16] Haden, S. S. P., Oyler, J. D., \&amp; Humphrey, J. H. (2009). Historical, Practical, And Theoretical Perspectives On Green Management. An Exploratory Analysis Management Decision, 47(7), 1041-1055. Doi: 10.1108/00251740910978287

[17] Hansen, M.T., Nohria, N. And Tierney, T. (1999) What's Your Strategy for Managing Knowledge?, Harvard Business Review, 77(2), (MarchApril 1999), 106-116.

[18] Kumar, J.A., Ganesh, L.S. (2011) Balancing knowledge strategy: codification and personalization during product development, Journal of Knowledge Management, 15(1), 118-135.

[19] Liu, H. Chai K.H., and Nebus, J.F., (2013) Balancing codification and personalization for knowledge reuse: a Markov decision process approach, Journal of Knowledge Management, 17(5), 755-772.

[20] Mcdonagh, P., \&amp; Prothero, A. (1997). Green Management: A Reader. London: Dryden Press.

[21] Murari, K., \&amp; Bhandari, M. (2011). Green HR: Going Green with Pride. Journal of Social Welfare and Management, 3, 107-110.

[22] Muster and Schrader Green Work-Life Balance: A New Perspective for Green HRM German Journal of Research in Human Resource Management, DOI 10.1688/1862 0000_ZfP_2011_02_Muster 141

[23] Opatha, H.H.D.N.P., \&amp; Arunrajah, A. Anton, \&amp; Nawaratne,

N.N.J. (2015), Green Human Resource Management Practices: A Review, Sri Lankan Journal of Human Resource Management, 5(1), 1-16.

[24] Owen, D. (1992). Green Reporting: Accountancy and the Challenge of the Nineties. London: Chapman Hall, 3-33.

[25] PRME. (2010). The 6 Principles for Responsible Management Education. Accessed online at http://www.unprme.org/the-6principles/index.php.

[26] R. M. Hodgetts, and K. W. Hegar, Modern Human Relations at Work

(10th ed.), Mason, U.S.A.: Thomson Higher Education, 2004.

[27] Robinson, F. (2008). Going green: what does it really mean? [Online] Available at: http:/ ezinearticles.com/?Going-green!What-does-it-really-mean?\&kd=22679 26.

[28] S. Ahmad, and R.G. Schroeder, "The impact of human resource management practices on operational performance: recognizing country and industry differences," Journal of Operations Management, vol.21, pp. 19-43, 2003.

[29] S. Sudin, "Strategic Green HRM: A proposed model that supports CorporateEnvironmentalCitizenship(PublishedConferenceProceedings style), The International Conference on Sociality and Economics Development, Singapore: IACSIT Press, 2011, pp.79-83.

[30] Sabherwal, R., Chan, Y. E. (2001). Alignment between business and is strategies: a study of prospectors, analyzers, and defenders, Information Systems Research, 12(1), 11-33.

[31] Shackelford, A., Sun, P. (2009) Knowledge management strategy employed in a sme: the case of a building materials supplier, Journal of Knowledge Management Practice, 10(4), December 2009.

[32] Sudin, S. (2011) 'Strategic green HRM: a proposed model that supports corporate environmental citizenship', Paper presented at the International Conference on Sociality and Economics Development, Kuala Lumpur,

Malaysia, 4-5 June, IPEDR, IACSIT Press, Singapore, Vol. 10

[33] Sudin, S. (2011). Fairness of satisfaction with Performance Appraisal Process. Journal of Global Management,2(1), 67-73. Warming. New York: mcgrow-Hill.

[34] Wehrmeyer, W., \& Parker, K (1996). Identification and Relevance of Environmental Corporate Cultures as Part of a Coherent Environmental Policy. In W. Wehrmeyer (ed.), Greening People (pp. 163184).Sheffield, England: Greenleaf Publishing.

[35] Wright, P. M., Dunford, B. B. \& Snell, S. A. (2007): Human resources and the resource based view of the firm. In: Schuler, R. S. \& Jackson, S. E. (ed.): Strategic Human Resource Management. 2nd Edition. Oxford: Blackwell Publishing.

[36] Wright, P.M., Dunford, B.B., \& Snell, S.A., 2001, Human resource and the resource based view of the firm. Journal of Management,27, 701-721.

[37] Zack, M. H. (1999). Developing a knowledge strategy. California Management Review, 41(3), 125-145.

\section{AUTHORS PROFILE}

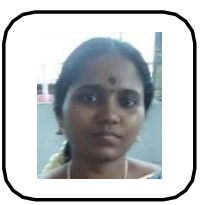

M. Suba considered B.Com (Computer Application) in V.P.M.M Arts and Science College; Srivilliputtur completed his M.B.A in Maharaja building College, Coimbatore and have been fill in as an associate teacher in V.P.M.M Arts and Science College, Srivilliputtur doing his exploration in Kalasalingam Academy of Research and Education. Distributed to papers in Scopus recorded diary one in Journal of Advanced Research and Dynamical Control System and one in International Journal of Pure and Applied Mathematics

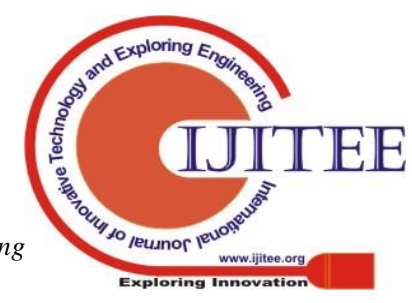


Dr. S. B. Inayath Ahamed Surname (Initial complete name): Sikkandar Basheer Ahamed Finished his B.E (Electrical And Electronics Engineering) in Sona College Of Technology, Salem. What's more, he examined his M.B.A in B S Abdur Rahman University Finished his PhD degree PRIMS . Functioning as an Assistant Professor in

Kalasalingam Academy of Research and Education (Deemed to be University). Granted as best scientist by IARA 